\title{
Research Square \\ Linkage of Sustainability to Environmental Impact Assessment Using Ecosystem Services Concept; Lessons from Thailand
}

\section{Kanokporn Swangjang ( $\sim$ kswangjang@gmail.com )}

\section{Research}

Keywords: Environmental Assessment, Ecosystem Services, Environmental Impact Statements, Content Analysis, Sustainability, Thailand

Posted Date: July 29th, 2020

DOl: https://doi.org/10.21203/rs.3.rs-46876/v1

License: (c) (i) This work is licensed under a Creative Commons Attribution 4.0 International License. Read Full License 


\section{Abstract}

Ecosystem Services (ES) could support Environmental Assessments (EAs) purpose towards sustainable approaches. This study systematically analyzed the ES contents of Environmental Impact Statements (EISs) to ascertain whether they addressed appropriate data that could be used as a tool for sustainable project implementation. Three levels of EISs including Environmental Health Impact Assessments (EHIA), Environmental Impact Assessments (EIA), and Initial Environmental Examinations (IEE) were analyzed. The results indicated that the quality of EISs which reflect the ES depended primarily on the project type. Relationships among ecological, social and economic components, based on land use consideration were crucial to consider the supply of resources and the demands made by the project. However, indirect effects, especially residual and cumulative impacts and alternative evaluations were lacking. Mitigation and monitoring specifications were satisfied, but could not guarantee the efficiency of project control due to lacking of mitigation hierarchy. The weakness of ecological impact analysis directly concerned biodiversity compensation, which links to net loss and net gain in ecosystem. The possibility of ES integration in EAs was reflected by the limitations and opportunities detailed in the content which was finally developed.

\section{Introduction}

Ecosystem services (ES) can be defined as the benefits that people obtain from ecosystems (the Millennium Ecosystem Assessment, MEA 2015). This idea is a valuable tool for transforming ecological knowledge into economic information, quantifies natural resource management, and enhances the decision-making process for developers (Potschin et al. 2016; Engel et al. 2017). ES directly support the goals of sustainable development (Schröter et al. 2017) since they include a wide variety of benefits for people from existing or ecosystems, and they affect ecological sustainability, social equity, and economic efficiency (Geneletti 2013). Since 2007, interest in the theory of ES and its relevance to policy implementation have increased (Costanza 2016), and ES have become particularly important in the field of international politics (Maron et al. 2017; Ingram et al. 2018). ES are grouped into four categories (MEA 2015): supporting services are natural processes that maintain other ES categories (Landsberg et al. 2011); provision services deliver ecosystem products (Costanza et al. 2016); regulating services control ecosystem processes, for example, through biogeochemical cycles and biophysical structures at different scales (Fürst et al. 2016); and cultural services are the intangible benefits that people get from nature (Sanna and Eja 2017). These categories reinforce the understanding of both supply and demand in ecosystems and carrying capacity. Potschin et al. (2016) noted that ES are used to support the relationship between environmental assessment, the ecosystem, and monitoring. Such linkages provide the structure in multi-purposes for sustainability which is the dimensions of environment, social and economic (Atun et al. 2018). However, the adaptation of the ES approach is based on a different purpose (Balvanera et al. 2016). Among these is the Environmental Impact Assessment (EIA).

Since its adoption by the National Environmental Policy Act (NEPA) in the United States in 1969, ElA has become an increasingly familiar term in both developed and developing countries. Over the following five 
decades, EIA requirements have been adopted in various forms in planning, policy, and higher levels of legal hierarchy (Elvan 2018). The development of ElAs in more than 80 countries is ongoing, in terms of laws, regulations, and implementation (Morrison-Saunders et al. 2014). At the same time, EIA knowledge is diversifying, not just at project level but also at strategic levels and in many disciplines (Geneletti 2013). EIA helps to ensure that environmental and socio-economic issues are identified and addressed throughout the planning and implementation phases of projects and the higher levels (Victor and Agamuthu 2014; Elvan 2018). It should provide sufficient information and justification to enable decisions to be made, based on predictions of the potential effects of the development, and identification of ways to reduce and mitigate unacceptable impacts (Wathern 1999). It is understood that the EIA is one of the mechanisms for regulating the environment and all development projects related to sustainable development (Höjer et al. 2008; Retief et al. 2014; Morrison-Saunders et al. 2014).

In 1992, Agenda 21: Principle 17, United Nations Conference on Environmental Development (UNCED) indicated:

Environmental Impact Assessment, as a national instrument, shall be undertaken for proposed activities that are likely to have a significant adverse impact on the environment and are subject to a decision of a competent national authority.

Although the target of the EIA is to support sustainable development in the project implementation, it remains imperfect (Swangjang 2018). One reason for this is that, at all stages of the EIA, it depends on legal enforcement in each country and region. The ES concept considers the relationship between the supply and the demand of the ecosystems, which are affected by a project's sustainability. Thus, it involves not only the function of the ecosystem but also socio-economic development. ES could contribute to sustainability through changes in environmental and economic factors (Meylan et al. 2017) and is closely related to people's ways of life (Sanna and Eja 2017). In contrast, imbalances between ES supply and demand can show the unsustainability of a project's development. Thus, ES can support the EIA purpose in line sustainability. The research concerning the integration of ES in EIA has received increasing attention over the past ten years (Cruz-Garcia et al. 2017; McDonough et al. 2017; Lerouge et al. 2017). Landsberg et al. (2011) initiated a framework for incorporating ES in EIA that considered the interaction between the project and human well-being as the direct and indirect drivers of ecosystem change. Karjalainen et al. (2013) incorporated ES into EIA by using multi-criteria decision analysis (MCDA) and found that the concept of ES could add value to the assessment process. Honrado et al. (2013) developed a framework to analyze EIA practices and inferred the ES based on evidence provided by the EIA and Strategic Environmental Assessment (SEA) documents and supporting information. Tallis et al. (2015) provided an integrated framework for the improvement of biodiversity and the mitigation measures of ecosystem services that could improve the impact assessment method. The critical analysis of the potential role of ES in five case studies by Baker et al. (2013) provided a comprehensive approach, in which the ES were fully managed for the impact assessment framework. In the approach of Geneletti (2013), the impact assessment was used as an essential tool to focus on spatial planning policies for future ES. Many ES researches have been conducted recently in Europe and the United States. ES in 
relation to EIA have also been recognized in Asian regions. The study by Shoyama et al. (2017) examined the approaches used in the evaluation of ES and found that modeling and biophysical indicators were the most commonly used methods, but the impairment of geographical distribution and the practical use of models was still limited. Abcede Jr and Gera (2018) found that the inconsistencies and differences between different legal frameworks were the weak points in promoting ES for mining developments in the Association of Southeast Asian Nations (ASEAN). Many researches on ES in EIA have identified some limitations, but it has also led to the improvement and promotion of sustainable development in practice.

In Thailand, an ASEAN country, the concept of ES is new, even though Thailand is geographically located in the tropical zone where the ecosystem is complex and unique. ES were launched in the 11th National Economic and Social Development Plan 2012-2016 as part of the Sustainable Natural Resource and Environmental Management Strategy (Office of the National Economic and Social Development Board 2011), but it was not completely implemented. Currently, ES are stipulated in the 12th National Economic and Social Development Plan 2017-2021 to enhance the ecosystem approach and generate income from conservation, according to the principles of ES (Office of the National Council for Economic and Social Development Board 2015). Although the EIA in Thailand are very advanced, the promotion of ES for legal purposes is still at an early stage (Swangjang 2018). In contrast, EIA, as one of the Environmental Assessment (EA) approaches considered at project level, has been strengthened in all authority hierarchies. EIA in Thailand was officially initiated in 1975 as part of the National Environmental Quality Act (NEQA). It should be noted that EIA is the familiar term for EA at project level. It was prescribed in the Constitution of the Kingdom of Thailand in 1997, and since then has been changed over time until it was finalized in 2018. There are three levels of environmental impact study at project level (Table 1), namely Environmental Health Impact Assessment (EHIA), Environmental Impact Assessment (EIA), and Initial Environmental Examination (IEE). The type and size of development projects required for each study depend on the seriousness of the impacts. The details of the studies are somewhat different from each. EHIA documents are the most significance, both in terms of the details and the presentation of the project, while IEE documents give the least detail. 
Table 1

Comparison of IEE, EIA, and EHIA as stated by Thai legal enforcement

\begin{tabular}{|c|c|c|c|}
\hline Issues & IEE & EIA & EHIA \\
\hline \multirow{2}{*}{$\begin{array}{l}\text { Legal } \\
\text { enforcement }\end{array}$} & NEQA since 1992 & \multirow[t]{2}{*}{ NEQA since 1975} & \multirow{2}{*}{$\begin{array}{l}\text { Constitution of the Kingdom, } \\
\text { since } 2007\end{array}$} \\
\hline & $\begin{array}{l}\text { Government } \\
\text { Gazette }\end{array}$ & & \\
\hline \multirow{2}{*}{$\begin{array}{l}\text { The number of } \\
\text { projects } \\
\text { required } \\
\text { (as of 2020) }\end{array}$} & 2 projects $^{1}$ & \multirow{2}{*}{$\begin{array}{l}35 \text { projects } \\
\text { and } 3 \text { projects in } \\
\text { protected areas }\end{array}$} & \multirow{2}{*}{$\begin{array}{l}11 \text { projects } \\
\text { and not allowed in protected } \\
\text { areas }\end{array}$} \\
\hline & $\begin{array}{l}\text { and } 10 \text { projects } \\
\text { in protected } \\
\text { areas }^{2}\end{array}$ & & \\
\hline $\begin{array}{l}\text { Project } \\
\text { significance }\end{array}$ & Moderate impact & Moderate to high impact & The highest significance \\
\hline \multirow{2}{*}{$\begin{array}{l}\text { Public } \\
\text { participation }{ }^{3} \\
\text { (as of } 2020 \text { ) }\end{array}$} & 1 time & 2 times & 3 times \\
\hline & During EIA study & $\begin{array}{l}\text { During scoping and } \\
\text { drafting of the final } \\
\text { document }\end{array}$ & $\begin{array}{l}\text { During scoping, ElA study and } \\
\text { drafting of the final document }\end{array}$ \\
\hline
\end{tabular}

The framework of ES in EAs has been introduced and developed on a case by case basis, dependent on the nature of each region, and the development of knowledge in this discipline. However, most such studies have been conducted in developed countries. Thailand, as developing country, although both legal and organizational progress in EIAs is being made, the outcomes still do not meet the target of sustainable development (Swangjang 2018). To ensure a sustainable target in EA, integration of ES in environmental impact studies is one of the crucial approaches. This led us to investigate the content of Environmental Impact Statements (EISs) in Thailand to ascertain whether they addressed or clarified appropriate data to support ES for an effective EA that could be used as a tool for sustainable project implementation. The aim was to integrate the approach in order to strengthen ES in environmental impact studies which could be both direct and indirect factors for the EA effectiveness.

\section{Method}

The selection of the EISs for review was based on a subjective view. EA studies at project level in Thailand comprised three types (IEE, EIA, and EHIA), based on legal applications (see Table 1). The selection criteria depended on judgments regarding a representative of each document type. For EIA, activities related to different types of projects were used, while for IEE, the consulting firms or approved projects were used. Therefore, condominium and housing projects, studied by different consultant companies, were selected as an example for IEE. An exploration and oil production project was selected for EIA because it had a significant impact, and its project activities were different from condominium project. For EHIA, the assessment year was used because the project activities for all EHIA were classified 
as high significant impacts. Different generations of EHIA over time illustrated the development of EHIA studies. The selected EISs are shown in Table 2.

Table 2

Details of EIS

\begin{tabular}{|llllc|}
\hline EISs & $\begin{array}{l}\text { Consulting } \\
\text { Firms* }\end{array}$ & Project types & Project sizes & $\begin{array}{c}\text { Year } \\
\text { issued }\end{array}$ \\
\hline IEE1 & A & Condominium & 32 rooms located in a protected area & 2016 \\
\hline IEE2 & B & Housing & 1.6 hectares & 2016 \\
\hline EIA1 & C & $\begin{array}{l}\text { Petroleum } \\
\text { Exploration }\end{array}$ & Area of 2 kilometers radius & 2007 \\
\hline EIA2 & B & Condominium & 70 rooms located in a protected area & 2016 \\
\hline EHIA1 & D & Petrochemical & $\begin{array}{l}\text { Production expanded to 90,000 } \\
\text { tons/year }\end{array}$ & 2012 \\
\hline EHIA2 & D & Battery factory & > 10 tons/day & 2016 \\
\hline $\begin{array}{l}\text { Note As to confidential reason, alphabet symbols were represented as the name of consultant } \\
\text { companies. }\end{array}$ & & & \\
\hline
\end{tabular}

A qualitative analysis of ES in environmental impact studies was conducted by content analysis. The review of EIS contents were originally conducted by Lee and Colley (1990). The review criteria have been adapted from time to time, depending on the intended purpose. Several studies have been developed that involved a review of EIS contents (Wood et al. 1991; Lee and Dancey 1993; Maquire 1994; O'Shea 1994; McGraph and Bond 1997), and a review of the EIA guidelines (Swangjang et al. 2004). However, no consideration of EISs that reflected ES has been carried out for tropical countries, where ES are well supplied. Analysis of EISs should demonstrate whether the revealed information provides an adequate basis for considering ES in practice.

The criteria for the main aspects of ES in the environmental impact studies were: existing environment; impact assessment; and mitigation measures, and monitoring measures. The concept of audit criteria was adopted and included three main contents, namely; the sufficient data of EIA, the linkage data to ES, the data which directly support ES outcome (Table 3). A variety of bibliographic sources (Kanokporn and lamaram 2010; Landsberg et al. 2011; Chanchitpricha and Bond 2013; Geneletti 2013; Karjalainen et al. 2013; Morrison-Saunders et al. 2014; Eccleston 2014; Tallis et al. 2015; Rosa et al. 2016; Baresi et al. 2016; Phuc 2016; Costanza et al. 2016; Geneletti 2016; Potschin et al. 2016; Swangjang 2018) were used. 
Table 3

The criteria for linkage of ES to EA

\begin{tabular}{|lll|}
\hline Stages of EIA study & Criteria & Codes of criteria \\
\hline Baseline study & Sufficiency for baseline data & B 1-B 8 \\
& Provide framework to ES & B 7-B 8, B13-B 14 \\
& Content support to ES & B 9-B 16 \\
Impact Assessment & Sufficiency for impact assessment & I 1-I 8 \\
& $\begin{array}{l}\text { Content support loss/gain in } \\
\text { ecosystem }\end{array}$ & I 9-I 11 \\
& Content support to ES & I 6-I 17 \\
& Linkage to ES compensation & I 15-I 17 \\
\hline $\begin{array}{l}\text { Mitigation and monitoring } \\
\text { measures }\end{array}$ & Sufficiency for mitigation/monitoring & M 1-M 3, M 9-M 11 \\
& Provision the linkage to ES & M 4-M 5 \\
& Mitigation/monitoring support ES & M 6-M 8 \\
\hline
\end{tabular}

These audit criteria were then classified with the coding of each category according to the content of the EISs. The extent to which EISs met these criteria was assessed subjectively on a five-point scale (Kanokporn and lamaram 2010) (Table 4). The total score for each category was calculated as an average, to reflect the content of EISs that supported ES.

Table 4

Criteria indicating the level of consideration

\section{Level Definition}

$5 \quad$ Provides very specific criteria related to the particular issues, in accordance with criteria setting, no additional information required

4 Provides adequate information on issues required for ES in an environmental impact study, although some issues need to be supplemented, gaps are only minor

3 Only provides detail demanded, necessary additional information regarding the criteria in question, is not included

2 Provides general details without the response to setting criteria

1 Does not provide the necessary information in the particular category

\section{Results And Discussion}

Ecosystem services in environmental impact studies 
The criteria reflecting the quality of the environmental impact study in support of the ES were divided into three parts: the baseline description (project description and existing environment), impact assessment, and mitigation and monitoring measures, as following.

\section{Baseline study}

Considering the baseline description as the initial stage (Table 5), the quality of the information in the EHIAs was higher than in the IEEs, while the type of project affected the baseline data in the EIAs. For all EISs, the data presentation was scientifically well defined, but the area of the study was not flexible. A defined distance of either 1 or $5 \mathrm{~km}$ from the project location was frequently mentioned in the EISs. The balanced among environmental and socio-economic issues were based more on formal guidelines than the characteristics of the specific area. Alternative identification, land use, and urban planning had satisfactory scores. The integration of land use and the ecosystem was linked to social, economic, and environmental issues. Ecological data is important as it can provide the necessary framework, not only to obtain an effective EA (Dunster 1992) but also to provide spatially explicit data for ES (Mandle and Tallis 2016). The presentation of the ecological baseline in terms of an ecological index could justify the category of supporting services in ES. The linkage between the ecological, social, and economic data based on land use consideration was an advantage which were sufficient to consider the balance between the supply of resources and the demands made by the project on the ES, especially for EIA 1 (score 3) and EHIA 2 (score 4). The best presentation of the regulatory support was found in EIA 1 (score 4 ) in which both national legislation and the international agreement were provided. This directly supported the mechanism of regulating services during the baseline stage. As a result, basic information to support ES values in the EISs were most evident for EIA 1 (score 3) and EHIA 2 (score 4). 
Table 5

Values of ES in baseline study (B) of EISs content

\section{Criteria}

\section{Level of consideration}

IEE IEE EIA EIA EHIA EHIA Average

$\begin{array}{llllll}1 & 2 & 1 & 2 & 1 & 2\end{array}$

\begin{tabular}{|c|c|c|c|c|c|c|c|}
\hline B 1. To specify likely project alternatives & 4 & 2 & 4 & 4 & 5 & 5 & 4.00 \\
\hline B 2. To specify a flexible boundary area & 2 & 1 & 3 & 1 & 3 & 3 & 2.17 \\
\hline $\begin{array}{l}\text { B 3. To consider the characteristics of the } \\
\text { area and the appropriateness of } \\
\text { conservation and development. }\end{array}$ & 3 & 3 & 3 & 2 & 2 & 3 & 2.67 \\
\hline
\end{tabular}

B 4. To consider land use

44

B 5. To consider urban planning

$5 \quad 5$

B 6. To consider international agreement

B 7. To identify reasons to support the balance between environment and socieeconomic indicators

B 8. To consider the linkage between ecological and socio-economic factors

B 9. To identify a specific ecological boundary

B 10. To identify ecosystem types

B 11.To present and review legislation related to biodiversity

B 12. To consider a sensitive area for biodiversity

B 13. To visit the study area based on the features of its biodiversity

B 14. To detail the laws and regulations that contribute to sustainable development.

B 15. To integrate ecological, social, and economic data based on land use consideration

B 16. To provide priority of suppy and demand on the basis of baseline information

Average

$2.13 \quad 2.00$

3

5

5

5

4.33

1

1

12

$4 \quad 1$

5

5

5

4.33

1.50

2

21

$1 \quad 1$

$1 \quad 1.33$

12

31

1

$4 \quad 2.00$

$1 \quad 1$

32

1

$5 \quad 2.17$

$\begin{array}{ll}2 & 2 \\ 1 & 1\end{array}$

$4 \quad 2$

1

$5 \quad 2.67$

22

31

1

$4 \quad 1.83$

3

2

1

$4 \quad 2.33$

11

31

$\begin{array}{lllllll}2 & 2 & 4 & 1 & 1 & 3 & 2.17\end{array}$

$\begin{array}{lllllll}2 & 2 & 3 & 2 & 2 & 4 & 2.50\end{array}$

$\begin{array}{lllllll}2 & 2 & 3 & 2 & 1 & 4 & 2.33\end{array}$

(1)




\section{Impact Assessment}

In the next phase, the impact assessment (Table 6), the components presented in the baseline data (project description and existing environment sections) could be used to evaluate impacts or be combined with other environmental components in impact assessments of a specific environmental component. For example, at the EHIA level, air quality, terrain, and land use were combined to evaluate impacts on air quality. In contrast, many components were presented only as basic data and not used further for impact assessment. According to the contents, the highest average score (2.63) was for EIA 1. In this EIS, the consistency of the causes of the impacts that affected the sustainable components was considered based on biodiversity within the proposed area. However, for the other EISs, the correspondence of many criteria revealed the inadequacy of using the baseline data in evaluations of project impacts. Although some mathematical models were used for some components, in particular, air quality, quantitative details were used only the values of specific parameters, without connecting the effects with the supply and demand in the ecosystem. Due to the failure to incorporate indirect effects in the impact assessment, the connection to the ecosystem based was at a low level. These details were, for example, "species of organisms are so common hence a low impact is predicted" or "... the project's wastewater was collected in the combined wastewater treatment system, so the "impact on biological resources is negligible." According to Tallis et al. (2015), ES in EAs should estimate the impact on their value and be included in ES delivery. The assessment of impacts on a single component did not accurately reflect the benefit of supply and demand in ecosystem. The incorporation of the 'no net loss' and 'net gain' concepts in biodiversity, together with the other biodiversity criteria, was insufficient due to the failure to conduct further assessment of indirect impacts, especially residual and cumulative impacts. Furthermore, a lack of alternative evaluations of the project was the weakest point for all EISs, even if these criteria had satisfactory assessment scores in the baseline phase. In contrast, the best average score for the impact assessment was for the consideration of the project life cycle and the members of public who were affected (score 3.00). Surprisingly, for EHIA 2, the assessment of impact was deficient, with a score of 2.00, although the quality of the baseline were satisfactory. This is one of the problems in EA studies, which use more of the budget for the presentation of data, without making the necessary budget available for the subsequent phases. 
Table 6

Values of ES in impact assessment (I) of EISs content

Criteria
Level of consideration

IEE1 IEE2 EIA EIA EHIA EHIA Average

$\begin{array}{llll}1 & 2 & 1 & 2\end{array}$

11. To assess the impact covered by the $\quad \begin{array}{llllllll} & 4 & 4 & 3 & 3 & 3 & 1 & 3.00\end{array}$ project life cycle

12. To analyze project alternatives

13. To assess impacts based on an ecological baseline

I 4. To consider the other sustainable components

I5. To cover all affected members of the public

16. To clarify ecological impact identification

17. To clarify ecological impact evaluation

18. To analyze the ecological impact, focusing on the risk to ecosystems

1

22

$23 \quad 3$

3

2

3

2.50

$\begin{array}{lll}3 & 2 & 4\end{array}$

43

3

3

3.00

22

2

3

1

1

3

2.00

22

3

1

1

22

23

3

1

1 9. To assess the impact on qualitative biodiversity

I 10. To assess the impact on quantitative biodiversity

I1. To assess the impact on the loss or gain of biodiversity

I12. To consider impact severity based on the sensitivity of biodiversity

I 13. To consider impact severity based on the resiliance of biodiversity

I 14. To consider impact severity based on the recovery of biodiversity

115. To assess redidual and/or cumulative impacts

I 16. To arrange the impact hierarchy on 1 biodiversity

I17. To assess ecological aspects consistent with the project characteristics.

$\begin{array}{lllllll}1 & 1 & 1 & 1 & 1 & 1 & 1.00\end{array}$

1

1

31

1.33

2

3

3

2

1

3

2.33 


\begin{tabular}{|c|c|c|c|c|c|c|c|}
\hline \multirow[t]{3}{*}{ Criteria } & \multicolumn{7}{|c|}{ Level of consideration } \\
\hline & IEE1 & IEE2 & EIA & EIA & EHIA & EHIA & Average \\
\hline & & & 1 & 2 & 1 & 2 & \\
\hline Average & 1.69 & 1.69 & 2.63 & 1.63 & 1.38 & 2.00 & 1.83 \\
\hline
\end{tabular}

\section{Mitigation and Monitoring Measures}

With regard to mitigation and monitoring measures (Table 7), the best average score (3.55) was once again for EIA 1, which was a well-defined requirement for project control activities. This issue was significant because the impact assessment output was a tool for project implementation. Mitigation and monitoring identification in the EHIAs were better than in the IEEs. Although basic details of mitigation and monitoring implementations were satisfactory, they were not guarantee the efficiency of project control. This was particularly the case for mitigation hierarchy, which can connect project control to biodiversity offsets. Consequently, biodiversity offsets, which are directly related to supply in the ecosystem, were lacking for IEEs and unclear for EHIAs. The best score was EIA 1, in which the consideration of biodiversity loss and the programs to control it were specified and covered the project lifecycle. An alternative aspect was lacking for all EISs under review. However, the identification of the chance to enhance or change mitigation measures in case of the future finding of unpredictable impacts was crucial for mitigation development. 
Table 7

Values of ES in mitigation and monitoring measures (M) of EISs content

Criteria

Level of consideration

IEE1 IEE2 EIA1 EIA2 EHIA1 EHIA2 Average

M 1. To identify the measures based on survey data and public opinion

$\begin{array}{lllllll}2 & 3 & 5 & 3 & 2 & 4 & 3.17\end{array}$

M 2. To identify the measures agreed

with the result of the impact

$\begin{array}{lllllll}4 & 4 & 5 & 3 & 3 & 3 & 3.67\end{array}$

assessment

M 3. To consider the alternative in

$1 \quad 1 \quad 1-1$

$2 \quad 1$

1.17

measure identification

M 4. To identify mitigation of

1

3

31

1

2

1.50

biodiversity

M 5. To consider the residual impact

3

5

1

3

3

2.67

M 6. To identify the compensation of

1

the loss of biodiversity of the species to

the ecosystem levels

M 7. To consider mitigation hierarchy

M 8. To establish the compensation

plan for ecosystems

M 9. To give the opportunity to enhance or change the mitigation

M 10. To give the opportunity to enhance or change the monitoring

M 11. To consider the achievement of measures

Average

$1.91 \quad 1.55$

3.55

1.45

2.45

2.55

2.24

The scores for the quality of the baseline information in the different types of EISs were in the range 2.00-3.75. Surprisingly, the quality of the information for impact assessment, which is a crucial stage, was found to have the lowest average score (1.83). For mitigation and monitoring, the average score was 2.24. The project type influenced the quality of the mitigation and monitoring, as the scores for EHIAs were higher than those for IEEs (Fig. 1).

\section{The integration of ecosystem services in environmental impact studies}


It is important for the administration of ES to be included in environmental impact studies. The role of the ES can improve the understanding of the ecosystem mechanisms resulting from the project activities. According to Karjalainen et al. (2013), ES may be considered in the early stage of an EA study through mitigation and monitoring. The possibility of ES integration in EAs was reflected by the limitations and opportunities detailed in the contents, see Table 8.

The findings of this study are initiated how ES could link in environmental impact study, as follows. Firstly, in the scoping phase, the selection of appropriate sustainability indicators should be focused and assessed throughout the EA study phase. However, the adequacy of the biodiversity baseline and its link with the other components is important in providing satisfactory information for the services demanded from and supplied by the ecosystem (Yamaura et al. 2017). Project activities should be the main consideration for determining the demand for natural resources, whereas the biodiversity component, from species to ecosystem, serves as the supply within the specified area. Biodiversity is important in contributing to ES that promote livelihoods and well-being (Huge et al. 2017). In EA studies, biodiversity pertains to ecological study as a primary component that could support project development in accordance with sustainable approaches (Wathern 1999; Sadler 1999; Mörtberg et al. 2007; Fuller et al. 2007; Kotwal et al. 2008; Briggs and Hudson 2013; Huge et al. 2017). In the initial stage, the quality of the ecological content is crucial. Levels of biodiversity change will vary during the duration of the project. Therefore, these considerations must be accounted for the EIA methodology (Mörtberg et al. 2007; Thompson 2007). The flexibility of impact boundary is related to the nature of the study area. Basic criteria, including factors related to survey planning, the flexibility in size of the proposed areas, the methods applied to specific ecological groups, and the initial site visit are important in determining the quality of baseline supply and demand for an area.

The strength of the baseline data was based on scientific knowledge. The linkage of ecology and socioeconomic aspects to land use under the enforcement by Urban Planning was outstanding, and these relations could support the carrying capacity of such area. Fürst et al. (2016) indicated the importance of land use management as a factor supported by the regulating services concept. The flexibility of the biodiversity boundary was not included in the EISs evaluated. Consequently, those failure could not respond to the actual supply and demand within the ecosystem because the impacts on biodiversity were mostly indirect impacts resulting from physical impacts, such as air or water impacts. Moreover, existing quantitative studies, which consider changes at both the temporal and spatial scales of ecosystems, are critical for successful integration of ES and the environmental impact study (Sirami et al. 2007). The temporal scale, which affects both the baseline data and the impact assessment, should include the characteristics of species that occur and an interpretation of the impact predictions (Gontier 2007). Specification of the condition of the fauna and flora within the ecosystem is one approach that could support temporal coverage. This is vital in subsequent stages of the impact assessment. This lack of temporal data is problematic, especially for the small projects characterizing the IEE group, in which baseline data were only collected on a single date. 
For the impact assessment, the project phases should include the project lifecycle, at least in the construction and operational phases, and determine the resource demands. Loss and gain of biodiversity resulting from project activities should be the first priority for any impact assessment. According to Geneletti (2016), an impact assessment should depend on ES as the priority, but more legal guidance is needed that could indirectly assert the assessors. Baseline details should be further assessed for their impacts. Project alternatives, such as project sizes, locations or processes, presented in the baseline data should assess the impacts and be considered further for mitigation and monitoring. The weakness found by our study was the lack of alternative considerations throughout the stages of environmental impact studies. Remarkably, the impacts on ecosystems, from varying levels of human disturbance, were addressed in descriptive terms. This raised some uncertainty regarding the overall impact assessment, which had been done without consideration of biodiversity concepts such as species loss, project effects on the natural habitat, and community and ecosystem components. Ecological impact identification and evaluation and contributions to environmental change can be negative and/or positive, residual and/or cumulative, and significant and/or magnitude impacts. Impact projections affect subsequent project activities. For example, negative impacts should be a priority in effectively managing the reduction of adverse ecosystem effects.

Finally, the mitigation and monitoring specifications should consider the ways to maintain supply and demand in ecosystem with reasonable costs and benefits. Options for mitigation, through the mitigation hierarchy, can improve and maintain the well-being of affected beneficiaries from ES (Landsberg et al. 2011). Mitigation hierarchy is fundamental to EA practice for biodiversity offsets by the consideration of alternatives in program identification (Brownlie and Treweek 2016). Project compensation in practice should adhere to the mitigation sequence of avoid, minimize, rectify, reduce, and compensation or offsets (Villarroya and Puig 2010). These can compensate for the loss of ecosystem resulting from the project demands, and it is a crucial approach for incorporating ES in EAs.

The benefit of mitigation and monitoring was the inclusion of public opinion, in accordance with legal enforcement. Those response should reflect the actual requirement of the local public (Chaisomphob et al. 2004). For better implementation, the members of the public identified should be representative of the public concerned, and poverty in both income and well-being should be considered. According to the UN sustainable development goals adopted in 2015, poverty (Goal 1) also covers the poor in situations such as climate-related events and other shocks and disasters. Hence, all people should be considered equally.

Program achievements are a vital element of the program performance, and they are exhibited by the project control agencies during project implementation. In this regard, essential monitoring directly affects the likely implementation of EA in practice. The cost of monitoring implementation is a fundamental principle that touches upon all monitoring-related activities. The ways to improve performance relate to these aspects. Firstly, flexible programs are required by optimizing the design. Secondly, the period over which parameters should be monitored should be included in the programs. Thirdly, the efficiency of resource use in monitoring should be a focus. The consequences of giving 
appropriate attention to these factors would be a reduction in the costs of monitoring unimportant parameters that create wasted effort. These savings could lead to better environmental management.

The success of mitigation and monitoring is compliance. The effectiveness of mitigation and monitoring programs, all of which are defined in official documents, is not a guarantee that the programs will be implemented. This is confirmed by the results of this study in the real estate projects. The mitigation and monitoring actions may have made it difficult to measure the accuracy of impact prediction since the results of the impact assessment were not the key element in identifying the programs. Consequently, the performance during project implementation was questionable.

Roe and Geneletti (2016) indicated that Biodiversity underpins the delivery of essential ES on which the whole of humanity is dependent. However, it depends on the nature of the project and the environment where the project is located. To better incorporate ES, through eco-based objectives, in environmental impact studies, connections between biodiversity content and the different stages of an EA are strongly recommended. These points can help EA to support the sustainable development goals. 
Table 8

Integration of ES in EA study; opportunities and barriers

\begin{tabular}{|c|c|c|c|}
\hline EA stages & Opportunities & Barriers & $\begin{array}{l}\text { Approach to integrate ES in EA } \\
\text { study }\end{array}$ \\
\hline $\begin{array}{l}\text { Baseline } \\
\text { description } \\
\text { (project } \\
\text { description } \\
\text { and existing } \\
\text { environment) }\end{array}$ & $\begin{array}{l}\text { - The presentation had a } \\
\text { scientific basis. } \\
\text { - All projects complied } \\
\text { with the enforcement of } \\
\text { urban planning. } \\
\text { - Project alternative and } \\
\text { reasonable choices were } \\
\text { identified. } \\
\text { - Ecological, economic, } \\
\text { and social linkages were } \\
\text { considered through the } \\
\text { characteristics of land } \\
\text { use, especially for EIA } 1 \\
\text { and EHIA } 2 \text {. } \\
\text { - The information linking } \\
\text { to the ES was urban } \\
\text { planning, land use } \\
\text { features, and the } \\
\text { relationship between } \\
\text { project activities and } \\
\text { their ecosystem. }\end{array}$ & $\begin{array}{l}\text { - The boundary of } \\
\text { the study was fixed, } \\
\text { lacking the flexibility } \\
\text { of the surroundings. } \\
\text { - The determining } \\
\text { component } \\
\text { depended on the } \\
\text { official guidance } \\
\text { rather than project } \\
\text { activity and the } \\
\text { nature of area. } \\
\text { - The presentation of } \\
\text { ecological } \\
\text { information was } \\
\text { lacking, only } \\
\text { superficial } \\
\text { information, } \\
\text { especially for IEE } \\
\text { projects. } \\
\text { - Survey and data } \\
\text { collection were only } \\
\text { done once. }\end{array}$ & $\begin{array}{l}\text { - Project activities and } \\
\text { biodiversity components based } \\
\text { on land use conditions are the } \\
\text { main supply and demand } \\
\text { considered for ecosystem } \\
\text { capacity. } \\
\text { - The environmental, social, and } \\
\text { economic components should } \\
\text { be considered equally } \\
\text { depending on the nature of the } \\
\text { proposed area. } \\
\text { - Spatial and temporal coverage } \\
\text { should be specified } \\
\text {-Biodiversity context is based } \\
\text { on the quality of ecological } \\
\text { study in the EA. }\end{array}$ \\
\hline $\begin{array}{l}\text { Impact } \\
\text { Assessment }\end{array}$ & $\begin{array}{l}\text { - Impact assessment } \\
\text { covered project life cycle. } \\
\text { - The considerations of } \\
\text { the affected public were } \\
\text { satisfied. }\end{array}$ & $\begin{array}{l}\text { - Project alternatives } \\
\text { were not further } \\
\text { assessed for their } \\
\text { impacts. } \\
\text { - The weaknesses of } \\
\text { ecological impact } \\
\text { assessment were } \\
\text { remarkable, } \\
\text { especially the } \\
\text { linkage to } \\
\text { sustainable } \\
\text { development. } \\
\text { - Impact assessment } \\
\text { of indirect effects, } \\
\text { together with } \\
\text { residual and } \\
\text { cumulative impacts } \\
\text { failed. } \\
\text { - The impact } \\
\text { assessment was } \\
\text { ambiguous, except } \\
\text { for ElA1. }\end{array}$ & $\begin{array}{l}\text { - Baseline data should provide } \\
\text { the main issue to determine the } \\
\text { assessment of impacts on } \\
\text { service delivery and values of } \\
\text { ecosystems. } \\
\text {-Criteria for impact } \\
\text { identification and evaluation } \\
\text { should focus on biodiversity } \\
\text { values and cover both direct } \\
\text { and indirect impacts, together } \\
\text { with residual and cumulative } \\
\text { impacts. } \\
\text { - The spatial extent of impact } \\
\text { assessment should be } \\
\text { considered as the biodiversity } \\
\text { and associated consequent } \\
\text { mechanism depending on the } \\
\text { ES of the area. }\end{array}$ \\
\hline
\end{tabular}




\begin{tabular}{|c|c|c|c|}
\hline EA stages & Opportunities & Barriers & $\begin{array}{l}\text { Approach to integrate ES in EA } \\
\text { study }\end{array}$ \\
\hline $\begin{array}{l}\text { Mitigation } \\
\text { and } \\
\text { monitoring } \\
\text { measures }\end{array}$ & $\begin{array}{l}\text { - Public comments were } \\
\text { included in the } \\
\text { mitigation and } \\
\text { monitoring identification. } \\
\text { - Quality of mitigation } \\
\text { and monitoring were } \\
\text { based on project levels } \\
\text { related to the } \\
\text { enforcement by } \\
\text { competent agencies. }\end{array}$ & $\begin{array}{l}\text { - Mitigation } \\
\text { implementation was } \\
\text { questionable, } \\
\text { especially for IEE. } \\
\text { - Mitigation } \\
\text { hierarchy is not well } \\
\text { defined. } \\
\text { - Biodiversity } \\
\text { compensation of net } \\
\text { loss is not clear. } \\
\text { - Alternative } \\
\text { mitigation and } \\
\text { monitoring were } \\
\text { lacking } \\
\text {-Time span of } \\
\text { monitoring and } \\
\text { future modification } \\
\text { was lacking. }\end{array}$ & $\begin{array}{l}\text { - Mitigation hierarchy should be } \\
\text { highlighted. Avoidance of } \\
\text { impacts is initiated, with } \\
\text { subsequent hierarchy through } \\
\text { biodiversity offsets. } \\
\text { - Residual and cumulative } \\
\text { impacts are recognized for } \\
\text { future mitigation enhancement. } \\
\text { - Appropriate biodiversity } \\
\text { offsets should be designed and } \\
\text { depend on the landscape of the } \\
\text { area. } \\
\text { - Monitoring focuses on high } \\
\text { efficiency for project } \\
\text { implementation. }\end{array}$ \\
\hline
\end{tabular}

\section{Conclusion}

The findings provide some insight regarding the integration of ES in EA. The quality of EISs which reflect the ES depended primarily on the project type. In this regard, the legislation of the respective agency is supreme while the fundamental constraint has been found in real estate projects. Furthermore, the weakness of ecological impact analysis, from species level to biodiversity, directly concerns biodiversity compensation, which links the approach of environmental analysis to net loss and net gain in ecosystem. The warning of the ecosystem stock could provide the goods and services for the proposed project.

According to Goal 15 of the UN sustainable development goal (2015), the integration of ecosystem and biodiversity values into planning and development processes should promote. The results of this study confirmed that ES considered in environmental impact studies can be used to link the EA to the project's sustainability. ES could improve the impact assessment process (Abcede Jr and Gera 2018). Any project located in the environment requires services from the ecosystem, while the supply is limited by the impacts of the project activities on the ecosystem. Various groups interacted in the EA projects studied in this research. They included both those who obtained the benefit and those who experienced negative effects from the project activities. ES reflect the supply capacity of nature and are influenced by external drivers and human society. The level of human demand is the benefit that humans obtain from the ecosystem (Maron et al. 2017; Wei et al. 2017). In summary, the concept of ES could promote a sustainable development approach in EAs, in accordance with the Rio Declaration (1992) and with the ASEAN Agreement (ASEAN, 2017). 


\section{Abbreviations}

ASEAN - the Association of Southeast Asian Nations

EA - Environmental Assessment

EIA - Environmental Impact Assessment

EHIA - Environmental Health Impact Assessment

EISs - Environmental Impact Statements

ES - Ecosystem Services

IEE - Initial Environmental Examination

MEA - the Millennium Ecosystem Assessment

NEPA - the National Environmental Policy Act

NEQA - the National Environmental Quality Act

\section{Declarations}

\section{Ethical Approval and Consent to participate}

The manuscript was mainly conducted by content analysis. No animals or human were concerned.

\section{Consent for publication}

The author declares that this manuscript or any data contained is received the consent for publication.

\section{Availability of supporting data}

All data generated or analyzed in this manuscript are available from the author on reasonable request.

\section{Competing interests}

The author declare they have no competing interests.

\section{Funding}




\section{Authors' contributions}

The author has contribute to study the research, to write and analyse this manuscript.

\section{Acknowledgments}

This manuscript is part of the main research financed by the Office of the National Research Council of Thailand no. SURDI 590155. The resources were also supported by the Department of Environmental Sciences, Silpakorn University.

\section{References}

1. Abcede, Jr. R., \& Gera, W. (2018). Examining the coherence of legal frameworks for ecosystem services toward sustainable mineral development in the Association of Southeast Asian Nations. Ecosystem Services, 29, 228-239.

2. Association of Southeast Asian Nations (ASEAN). (2017). ASEAN a community of opportunities. Resource document. Association of Southeast Asian Nations. www.asean.org. Accessed15 April 2019.

3. Atun, R.A., Nafa, H., \& Türker, Ö.O. (2018). Envisaging sustainable rural development through contextdependent tourism: a case of northern Cyprus. Environment, Development and Sustainability, 21, 1715-1744.

4. Baker, J., Sheate, W.R., Phillips, P., \& Eales, R. (2013). Ecosystem services in environmental assessment-help or hindrance. Environmental Impact Assesment Review, 40, 3-13.

5. Baresi, U., Vella, K.J., \& Sipe, N.G. (2016). SEA integration in sustainable planning frameworks. Resource document. International Association for Impact Assessment. www.iaia.org. Accessed 20 November 2018.

6. Balvanera, P., Quijas, S., Martin-López, B., Barrios, E., Dee, L., Isbell, F., Durance, I., White, P., Blanchard, R., \& de Groot, R. (2016). The links between biodiversity and ecosystem services. In M. Potschin, R. Haines-Young, R. Fish, R.K.Turner (Eds.), Routledge Handbook of Ecosystem Services (pp. 45-61). Oxon: Earthscan.

7. Brownlie, S., \& Treweek, J. (2016). Biodiversity offsets for no net loss through impact assessmen. In D. Geneletti (Ed.), Handbook on Biodiversity and Ecosystem Services in Impact Assessment (pp. 364396). Cheshire: Edward Elgar.

8. Briggs, S., \& Hudson, M.D. (2013). Determination of significance in ecological impact assessment: past change, current practice and future improvement. Environmental Impact Assesment Review, 38, 16-25. 
9. Chaisomphob, T., Sa-nguanmanasak, J., \& Swangjang, K. (2004). Role of public participation in planning power plant projects in Thailand. Thammasat International Journal of Science and Technology, 9(1), 67-73.

10. Chanchitpricha, C., \& Bond, A. (2013). Conceptualising the effectiveness of impact assessment process. Environmental Impact Assesment Review, 43, 65-72.

11. Costanza, R. (2016). Ecosystem services in theory and practice. In M. Potschin, R. Haines-Young, R. Fish, R.K.Turner (Eds.), Routledge Handbook of Ecosystem Services (pp. 15-24). Oxon: Earthscan.

12. Cruz-Garcia, G., Sachet, E., Blundo-Canto, G., Vanegas, M., \& Quintero, M. (2017). To what extent have the link between ecosystem services and human well-being has been researched in Africa, Asia, and Latin America?. Ecosystem Services, 25, 201-202.

13. Dunster, J.A. (1992). Assessing the sustainability of Canadian forest management: progress or procrastination. Environmental Impact Assesment Review,12, 67-84.

14. Eccleston, C.H. (2014). The EIA book; managing and preparing Environmental Impact Statements. Boca Raton: Taylor\&Francis.

15. Elvan, O.D. (2018) Analysis of environmental impact assessment practices and legislation in Turkey. Environmental Science and Policy, 84, 1-6.

16. Engel, D., Evans, M.A., Low, B.S., \& Schaeffer, J. (2017). Understanding ecosystem services adoption by natural resource managers and research ecologists. Journal of Great Lakes Research, 43, 169179.

17. Fuller, R.M., Devereux, B.J., Gillings, S., Hill, A., \& Amable, G.S. (2007). Bird distributions relative to remotely sensed habitats in Great Britian: towards a framework for national modeling. Journal of Environmental Management, 84, 586-605.

18. Fürst, C., Frank, S., \& Inkoom, J.N. (2016). Managing regulating services for sustainability. In M. Potschin, R. Haines-Young, R. Fish, R.K.Turner (Eds.), Routledge Handbook of Ecosystem Services (pp. 328-342). Oxon: Earthscan.

19. Geneletti, D. (2016). Strengthening biodiversity and ecosystem services in impact assessment for better decisions. In D. Geneletti (Ed.), Handbook on Biodiversity and Ecosystem Services in Impact Assessment (pp. 477-485). Cheshire: Edward Elgar.

20. Geneletti, D. (2013). Assessing the impact of alternative land-use zoning policies on future ecosystem services. Environmental Impact Assesment Review, 40, 25-35.

21. Gontier, M. (2007). Scale issue in the assessment of ecological impacts using a GIS-based habitat model- A case study for the Stockholm region. Environmental Impact Assesment Review, 27, 440459.

22. Government Gazette ${ }^{a}$. (2019). Project types and sizes required environmental impact assessment. Number 136 Section 3 \& on 4 January 2562. Resource document. Office of Natural Resources and Environmental Policy and Planning. www.onep.go.th. Accessed 23 May 2019. 
23. Government Gazette. (2018). Guideline for environmental impact assessment of projects located in protected area. Number 135 Section $39 \unrhd$ on 21 February 2562. Resource document. Office of Natural Resources and Environmental Policy and Planning. www.onep.go.th. Accessed 23 May 2019.

24. Government Gazette ${ }^{b}$. (2019). Public participation in the stage of environmental impact assessment. Number 136 Section $36 \otimes$ on 8 February 2562. Resource document. Office of Natural Resources and Environmental Policy and Planning. www.onep.go.th. Accessed 23 May 2019.

25. Honrado, J.P., Vieira, C., Soares, C., Monteiro, M.B., Marcos, B., Pereira, H.M., \& Partidario, M.R. (2013). Can we infer about ecosystem services from EIA and SEA practice? A framework for analysis and examples from Portugal. Environmental Impact Assesment Review, 40, 14-24.

26. Höjer, M., Ahlroth, S., Dreborg, K-H., Ekvall, T., Finnveden, G., Hjelm, O., Hochschorner, E., Nilsson, M., \& Palm, V. (2008). Scenarios in selected tools for environmental system analysis. Journal of Cleaner Production, 16, 1958-1970.

27. Huge, J., Rochette, A.J., de Bisthoven, L.J., Dahdouh-Guebas, F., Koedam, N., \& Vanhove, M.P.M. (2017). Utilitarian framing of biodiversity shape environmental impact assessment in developing cooperation. Environmental Science and Policy, 75, 91-102.

28. Ingram, V., Van Den Berg, J., Van Oorschot, M., Arets, E., \& Judge, L. (2018). Governance options to enhance ecosystem services in cocoa, soy, tropical timber and palm oil value chains. Environment \& Management, 62, 128-142.

29. Karjalainen, T.P., Marttunen, M., Sarkki, S., \& Rytkonen, A.M. (2013). Integrating ecosystem services into environmental impact assessment: an analytic-deliberative approach. Environmental Impact Assesment Review, 40, 54-64.

30. Kanokporn, K. \& lamaram, V. (2010). Ecological impact assessment, conceptual approach for better outcomes. International Journal of Environmental Research, 5(2), 435-446.

31. Kotwal, P.C., Omprakash, M.D., Gairola, S., \& Dugaya, D. (2008). Ecological indicators: imperative to sustainable forest management. Ecological Indicators, 8, 104-107.

32. Landsberg, F., Ozment, S., Stickler, M., Henninger, N., Treweek, J., Venn, O., \& Mock, G. (2011). Ecosystem services review for impact assessment; introduction and guide to scoping. Resource document. World Resources Institute. www.wri.org. Accessed 4 July 2018.

33. Lee, N., \& Colley, R. (1990). Reviewing the quality of environmental statements, Occasional Paper No.24, EIA Centre, University of Manchester.

34. Lee, N., \& Dancey, R. (1993). The quality of environmental impact statements in Ireland and the United Kingdom: a comparative analysis. Project Appraisal, 8, 31-36.

35. Lerouge, F., Gulinck, H., \& Vranken, L. (2017). Valuing ecosystem services to explore scenarios for adaptive spatial planning. Ecological Indicators, 81, 30-40.

36. Maquire, D. (1994). A review of all ElSs submitted for Marina development, since July 1988: a case study of Malahide Marina. Dissertation, St.Patrick's College, Ireland. 
37. Maron, M., Mitchell, M.G.E., Runting, R.K., Rhyodes, J.R., Mace, G.M., Keith, D.A., \& Watson, J.E.M. (2017). Towards a threat assessment framework for ecosystem services. Trends in Ecology \& Evolution, 32, 240-248.

38. McDonough, K., Hutchinson, S., Moore, T., \& Hutchinson, J.M. (2017). Analysis of publication trends in ecosystem services research. Ecosystem Services, 25, 82-88.

39. McGraph, C., \& Bond, A. J. (1997). The quality of an environmental impact statement: a review of those submitted in Cork, Eire from 1988-1993. Project Appraisal, 12, 43-52.

40. Mandle, L., \& Tallis, H. (2016). Spatial ecosystem service analysis for environmental impact assessment of projects. In D. Geneletti (Ed.), Handbook on Biodiversity and Ecosystem Services in Impact Assessment (pp. 15-40). Cheshire: Edward Elgar.

41. Meylan, L., Gary, C., Allinne, C., Ortiz, J., \& Jackson, L. (2017). Evaluating the effect of shade trees on the provision of ecosystem services in intensively managed coffee plantations. Agriculture, Ecosystems \& Environment, 245, 32-42.

42. Millennium Ecosystem Assessment. (2015). Ecosystem and human well-being: a synthesis. Washington: Island Press.

43. Mörtberg, U.M., \& Balfors Knol, W.C. (2007). Landscape ecological assessment: a tool for integrating biodiversity issues in strategic environmental assessment. Journal of Environmental Management, $82,457-470$.

44. Morrison-Saunders, A., Pope, J., Gunn, J.A.E., Bond, A., \& Retie,f F. (2014). Strengthening impact assessment: a call for integration and focus. Impact Assessment and Project Appraisal, 32, 2-8.

45. Office of Natural Resources, Environmental Policy and Planning Thailand. (1992). Guidelines for Environmental impact assessment preparation. Resource document. Office of Natural Resources and Environmental Policy and Planning. www.onep.go.th. Accessed 24 December 2017.

46. Office of the National Economic and Social Development Thailand. (2011). The $11^{\text {th }}$ Nation Economic and Social Development Plan 2012-2016. Resource document. Office of the National Economic and Social Development. www.nesdb.go.th. Accessed 24 December 2017.

47. Office of the National Economic and Social Development Thailand. (2015). The $12^{\text {th }}$ Nation Economic and Social Development Plan 2017-2021. Resource document. Office of the National Economic and Social Development. www.nesdb.go.th. Accessed 24 December 2017.

48. O'Shea, A. (1994). The quality of environmental impact statements: a review of those submitted in Ireland in 1992. Dissertation, University of Dublin, Ireland.

49. Phuc, P. (2016). Mainstream biodiversity consideration in the Vietnam environment country safeguard. Resource document. International Association for Impact Assessment. www.iaia.org. Accessed 20 November 2017.

50. Potschin, M., Haines-Young, R., Fish, R., \& Turner, R.K. (2016). Ecosystem services in the twenty-first century. In M. Potschin, R. Haines-Young, R. Fish, R.K.Turner (Eds.), Routledge Handbook of Ecosystem Services (pp. 1-9). Oxon: Earthscan. 
51. Retief, F., Bond, A., Gunn, J.A.E., Pope, J., \& Morrison-Saunders. A. (2014). International perspectives on the strengthening of impact assessment through integration and focus. Impact Assessment and Project Appraisal, 32, 27-30.

52. Rio Declaration on Environment and Development. (1992). UN Conference on Environment and Development. Resource document. United Nations. www.un.org/documets/ga/conf151/aconf151261 annex1.htm. Accessed 3 September 2018.

53. Roe, D., \& Geneletti, D. (2016). Addressing the interactions between biodiversity conservation and poverty alleviation in impact assessment. In D. Geneletti (Ed.), Handbook on Biodiversity and Ecosystem Services in Impact Assessment (pp. 347-363). Cheshire: Edward Elgar.

54. Rosa, J., Novachi, L.E., \& Sanchez, L.E. (2016). Offsetting and compensating biodiversity and ecosystem services losses in mining. Resource document. International Association for Impact Assessment. www. iaia.org. Accessed 20 November 2018.

55. Sadler, B. (1999). A framework for environmental sustainability assessment and assurance. In J Petts (Ed.), Handbook of Environmental Impact Impact Assessment (pp. 12-32). United Kingdom: Blackwell Science.

56. Sanna, S., \& Eja, P. (2017). Recreational, cultural ecosystem services: How do people describe the value? Ecosystem Services, 26, 1-9.

57. Schröter, M., Stumpf, K.H., Loos, J., Oudenhoven, A.P.E., Böhnke-Henrichs, A., \& Abson, D.J. (2017). Refocusing ecosystem services towards sustainability. Ecosystem Services, 25, 35-43.

58. Sirami, C., Brotons, L., Burfield, I., Fonderflick,J., \& Martin, J.L. (2007). Is land abandonment having an impact on biodiversity? A meta-analytical approach to bird distribution changes in the north-western Mediterranean. Biological Conservation, 141, 450-459.

59. Shoyama, K., Kamiyama, C., Morimoto, J., Ooba, M., \& Okuro, T. (2017). A review of modeling approaches for ecosystem services assessment in the Asian region. Ecosystem Services, 26, 316328.

60. Swangjang, K., Wathern, P., \& Rochanaburanon, T. (2004). Ecological issues in Thai environmental assessment scoping guidance. Impact Assessment and Project Appraisal, 22, 271-281.

61. Swangjang, K. (2018). Comparative review of EIA in the Association of Southeast Asian Nations. Environmental Impact Assesment Review, 78, 33-42.

62. Tallis, H., Kennedy, C.M., Ruckelshaus, M., Goldstein, J., \& Kiesecker, J.M. (2015). Mitigation for one \& all: an integrated framework for mitigation of development impacts on biodiversity and ecosystem services. Environmental Impact Assesment Review, 55, 21-34.

63. Thompson, G.G. (2007). Terrestrial vertebrate fauna surveys for the preparation of environmental impact assessments; how can we do it better? A Western Australian example. Environmental Impact Assesment Review, 27, 41-61.

64. United Nations (1992). Rio Declaration on Environment and Development. Resource document. United Nations. www.un.org/documets/ga/conf151/aconf15126-1annex1.html. Accessed 3 September 2018. 
65. United Nations (2015). The 2030 Agenda for sustainable development. Resource document. United Nations. https://sustainabledevelopment.un.org/?menu=1300. Accessed 5 June 2019.

66. Victor, D., \& Agamuthu, P. (2014). Policy trends of strategic environmental assessment in Asia. Environmental Science and Policy, 41, 63-76.

67. Villarroya, A., \& Puig, J. (2010). Ecological compensation and impact assessment in Spain. Environmental Impact Assesment Review, 30, 357-362.

68. Wathern, P. (1999). Ecological impact assessment. In J Petts (Ed.), Handbook of Environmental Impact Impact Assessment (pp. 323-345). United Kingdom: Blackwell Science.

69. Wei, H., Fan, W., Wang, X., Lu, N., Dong, X., \& Zhao, Y. (2017). Integrating supply and social demand in ecosystem services assessment: A review. Ecosystem Services, 25, 15-27.

70. Wood, C., Lee, N., \& Jones, C.E. (1991). Environmental statement in the United Kingdom: the initial experience. Project Appraisal, 6, 187-194.

71. Yamuara, K., Sakaue, S., \& Washida, T. (2017). An assessment of global warming and biodiversity: CGE EMEDA analyses. Environmental Economics and Policy Studies, 19, 405-426.

\section{Figures}

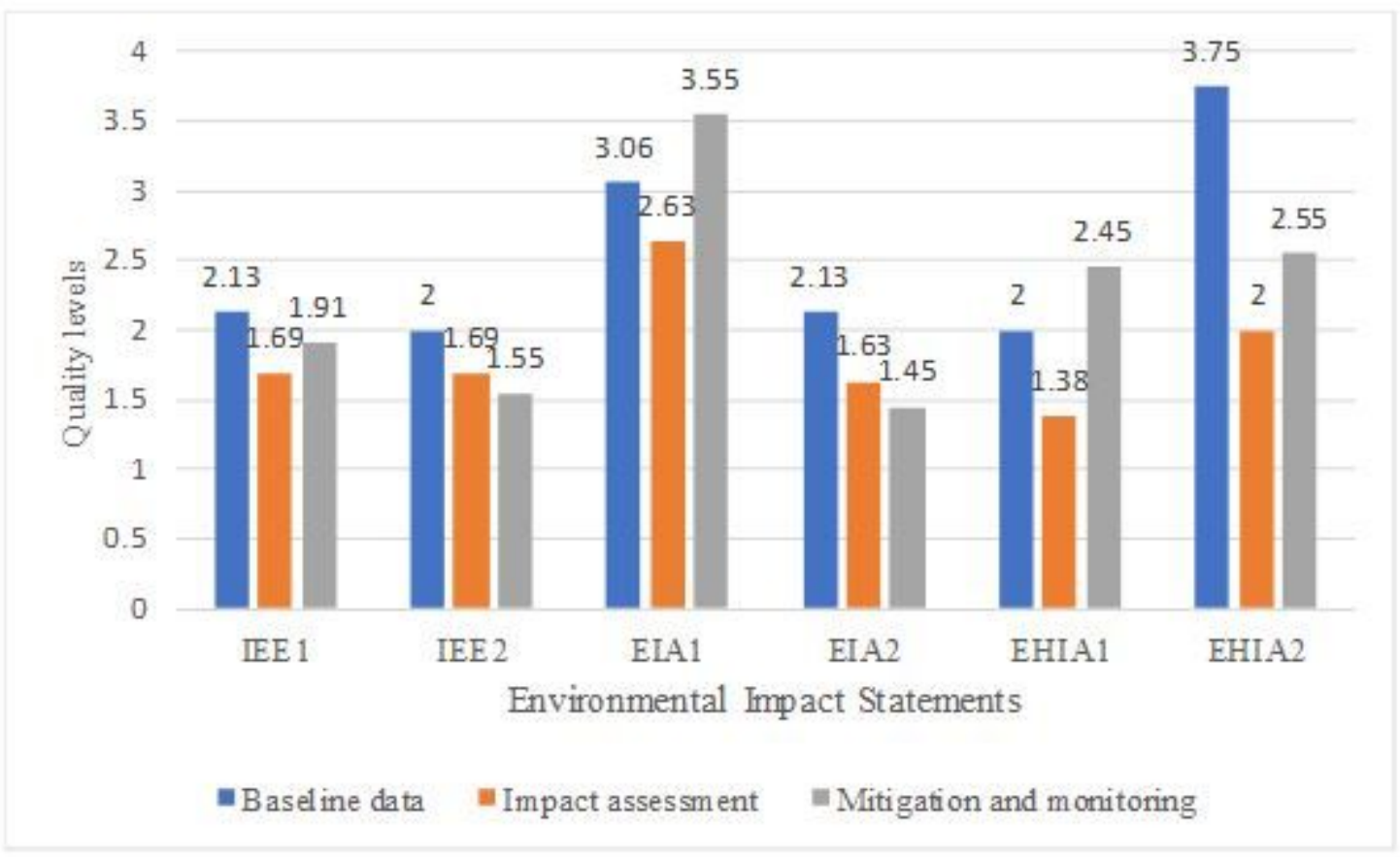

\section{Figure 1}

ES quality levels in Environmental Impact Statements 